\title{
EFFECT OF PRANAYAM ON VENTILATORY FUNCTIONS IN PATIENTS OF BRONCHIAL ASTHMA
}

\author{
Ajay Bhatt ${ }^{1}$, Sanjeev Rampallivar ${ }^{2}$
}

${ }^{1}$ Assistant Professor, Department of Physiology, MGM Medical College, Indore, Madhya Pradesh. ${ }^{2}$ Associate Professor, Department of Physiology, S. S. Medical College, Rewa, Madhya Pradesh.

\section{ABSTRACT}

\section{BACKGROUND}

Bronchial asthma is a chronic disease, which has a high rate of death. Medical intervention is very expensive and has bad side effects. The yoga as an alternative therapy might be useful in controlling respiratory outcome in asthma patients. With this aim, the study was carried out to study the effect of Pranayam on ventilatory functions in patients of bronchial asthma.

\section{METHODS}

Total 80 individuals with bronchial asthma participated in the study, out of which 40 taking medication and doing Pranayam for three months and other 40 participants taking only medication but not doing any exercise. The vitals and pulmonary parameters were recorded before and after 3 months.

\section{RESULT}

The improvement in vitals and pulmonary functions was found to be significant in participant taking medication and doing Pranayam for three months.

\section{CONCLUSION}

Our observations make it evident that yogic practices like Pranayam can be used along with medical treatment in decreasing the severity of bronchial asthma.

\section{KEYWORDS}

Bronchial Asthma, Pranayam, Respiratory Outcome, Yoga.

HOW TO CITE THIS ARTICLE: Bhatt A, Rampallivar S. Effect of pranayam on ventilatory functions in patients of bronchial asthma. J. Evolution Med. Dent. Sci. 2016;5(28):1453-1455, DOI: 10.14260/jemds/2016/341

\section{INTRODUCTION}

Asthma can be described as paroxysmal generalized airways obstruction and it is characterized by increased responsiveness of the lung to various factors such as emotions, stress, allergens, cigarette smoke, exercise, respiratory tract infection, fumes, dust, alcohol, drugs such as Aspirin and changes in environment. ${ }^{1}$ It is an important condition affecting between 100 to 150 million people around the globe, worldwide deaths from this condition have reached over 80,000 annually. ${ }^{2}$ India has an estimated 15-20 million asthmatics and rough estimates indicate prevalence between $10-15 \%$ in 5-11 year old children. Initially inhaled/oral medicinal therapy is helpful in management of the disease, but later on there is increase in financial burden, morbidity (More and more patients requiring oxygen therapy/respiratory support therapy) and mortality.

Yoga is a form of physical activity which consisting of various postures (Asana), breathing and meditation techniques (Pranayam). The yogic exercises may help in prevention, control and rehabilitation of many diseases. ${ }^{3}$ Yogic techniques such as breathing exercises, 'Pranayam' is a process by which 'Prana,' i.e. vital energy is controlled by regulating the breathing voluntarily.

The effect of regulating breath, i.e. Pranayam can be applied to multiple health problems including heart diseases,

Financial or Other, Competing Interest: None.

Submission 16-02-2016, Peer Review 15-03-2016,

Acceptance 19-03-2016, Published 07-04-2016.

Corresponding Author:

Dr. Ajay Bhatt,

H. No. 91, (New-94),

Scheme No-71, Sector-B,

Near Ranjeet Hanuman Temple,

Indore-452009, Madhya Pradesh.

E-mail:drajaybhatt@gmail.com

DOI: $10.14260 /$ jemds/2016/341 hypertension, lung diseases like asthma, stress disorders, depression, gastrointestinal disorders, etc. ${ }^{4}$ It is well known that the clinical course of a disease like chronic bronchial asthma is highly variable; being subject to many known and unknown factors, thus practicing Pranayam will be beneficial in regulating many aspects. With this view, the present study was carried out to study the effect of Pranayam on bronchial asthma patients.

\section{MATERIAL AND METHODS}

The present study was carried out in 80 patients selected from medical outdoors, asthma camp, yoga centres and various medical wards of S.G.M. Hospital, Rewa. The patient in the age group of 18 years to 72 years was included. Patients diagnosed to have bronchial asthma but showed evidence of complicating coronary artery disease, valvular heart diseases, hypertension, diabetes mellitus and any other systemic illness were excluded. The participants of the study were divided randomly in two groups, one is study group and other is control group.

The study group consisted of 40 such patients who consented to undergo yogic breathing exercises, i.e. Pranayam for three consecutive months without disrupting their medical treatment, while 40 patients of bronchial asthma taking only medical treatment were included in the control group. Control was informed not to do any new exercise program, but still maintain daily activities. Before starting the study permission was taken from Institutional Ethical Committee and consent were taken from each participant. The patients of study group were taught the techniques of various Pranayam (viz. Bhastrika, Kapalbhati, Anuloma-Viloma, Bhramri and Ujjayi) by demonstration.

Patients continued to practice Pranayam techniques regularly for a period of few days under supervision of expert faculty and after which they were allowed to practice at their 
residence for the duration of three months without discontinuing the medical treatment.

Detailed history, careful physical examination and the pulmonary function tests were conducted at the beginning of the study and again at the end of 3-month period of both the groups. Overall parameters determined were Pulse/min, Systolic Blood Pressure, Diastolic Blood Pressure, Resp. Rate/min, Peak Expiratory Flow Rate (PEFR; litre/minute), Forced Expiratory Volume in the first second (FEV1; litre), Forced Vital Capacity (FVC; litre)

Pulmonary functions which including FVC, FEV1, FEV1/FVC and PEFR were recorded by computerized spirometer 'Vitellograph' version 2.6 and disposable mouthpieces were used for each patient. After explaining and instructing the patients, they were asked to stand erect and take 3-4 normal breath. Then patients were asked to make a deep inhalation, i.e. to inhale maximally. Then patients were asked to hold the breath and to insert the mouthpiece of the instrument into the oral cavity and close the lips tightly around the mouthpiece, so that there is no gap between lips and mouthpiece thus preventing leakage of air.

Then patients were asked to close both the nostrils and to make a forceful and prolonged expiration into the mouthpiece and continue to exhale until he or she can blow no more. Three such technically acceptable consecutive tests were recorded by giving a rest of two to three minutes between each test and the best-performed test is selected for interpretation.

Patients were advised to perform the above Pranayams for the following duration.

\begin{tabular}{|c|c|c|}
\hline & Type of Pranayam & Duration \\
\hline 1. & Bhastrika Pranayam & $3-5$ minutes \\
\hline 2. & $\begin{array}{c}\text { Kapalbhati } \\
\text { Pranayam }\end{array}$ & $3-5$ minutes \\
\hline 3. & $\begin{array}{c}\text { Anuloma Viloma } \\
\text { Pranayam }\end{array}$ & $3-10$ minutes \\
\hline 4. & Bhramri Pranayam & $\begin{array}{c}\text { Minimum } 3 \text { times and maximum } \\
10 \text { to } 20 \text { times }\end{array}$ \\
\hline 5. & Ujjayi Pranayam & $\begin{array}{c}\text { Minimum } 3 \text { times and maximum } \\
10 \text { to } 20 \text { times }\end{array}$ \\
\hline
\end{tabular}

\section{Statistical Analysis}

Paired t-test was used to determine values before and after the treatment in both the groups and unpaired t-test was used to compare values in both the groups. Statistical assessments were done with SPSS Version 17. Values were expressed as Mean $\pm S D$ and $p \leq 0.05$ and $p \leq 0.001$ was significant.

\section{RESULTS}

\begin{tabular}{|c|c|c|c|c|}
\hline \multirow[b]{2}{*}{$\begin{array}{l}\text { Para- } \\
\text { meters }\end{array}$} & \multicolumn{2}{|c|}{ Study Group } & \multicolumn{2}{|c|}{ Control Group } \\
\hline & $\begin{array}{c}\text { Before } \\
\text { Mean } \pm \\
\text { S.D }\end{array}$ & $\begin{array}{c}\text { After } \\
\text { Mean } \pm \\
\text { S.D }\end{array}$ & $\begin{array}{c}\text { Before } \\
\text { Mean } \pm \\
\text { S.D }\end{array}$ & $\begin{array}{c}\text { After } \\
\text { Mean } \pm \\
\text { S.D }\end{array}$ \\
\hline $\begin{array}{c}\text { PULSE/ } \\
\text { min }\end{array}$ & $\begin{array}{c}91.1 \pm \\
8.02 \\
\end{array}$ & $\begin{array}{l}87.25 \pm \\
5.59 * \\
\end{array}$ & $\begin{array}{c}91.4 \pm \\
11.0 \\
\end{array}$ & $\begin{array}{c}87.55 \pm \\
6.36 \\
\end{array}$ \\
\hline $\begin{array}{l}\text { Systolic } \\
\text { blood } \\
\text { pressure } \\
\text { (mmHg) }\end{array}$ & $\begin{array}{c}124.35 \\
\pm 14.8\end{array}$ & $\begin{array}{c}118.2 \pm \\
7.38^{*}\end{array}$ & $\begin{array}{c}127.2 \pm \\
12.9\end{array}$ & $\begin{array}{c}123.6 \pm \\
9.01\end{array}$ \\
\hline $\begin{array}{l}\text { Diastolic } \\
\text { blood } \\
\text { pressure } \\
\text { (mmHg) }\end{array}$ & $\begin{array}{c}79.85 \pm \\
7.28\end{array}$ & $\begin{array}{c}77.6 \pm \\
5.16\end{array}$ & $\begin{array}{c}80.35 \pm \\
6.15\end{array}$ & $\begin{array}{c}78.7 \pm \\
4.38\end{array}$ \\
\hline
\end{tabular}

\begin{tabular}{|c|c|c|c|c|}
\hline Resp. & $22.4 \pm$ & $20.4 \pm$ & $24.35 \pm$ & $22.3 \pm$ \\
Rate/min & 3.74 & $2.79^{* *}$ & 5.02 & $3.61^{*}$ \\
\hline \multicolumn{3}{|c|}{ Table 1: Changes in the Vital Parameters like Pulse, } \\
Blood Pressure and Rate of Respiration in both groups \\
\hline
\end{tabular}

Data are presented as Mean \pm SD. Paired ' $\mathrm{t}$ ' test. ${ }^{*} \mathrm{p}<0.05$ and ${ }^{* *} \mathrm{p}<0.001$.

Table No. 1 present that a significant decrease in the pulse rate was observed in the patients who had undergone Pranayam practice as compared to control group. As regards the blood pressure, a significant reduction in systolic blood pressure was observed in study group as compared to the control group; however, the reduction in the diastolic blood pressure was not significant. The rate of respiration registered a highly significant reduction in the study group as compared to the significant fall in the control group.

\begin{tabular}{|c|c|c|c|c|}
\hline \multirow[b]{2}{*}{$\begin{array}{l}\text { Param } \\
\text { eters }\end{array}$} & \multicolumn{2}{|c|}{ Study Group } & \multicolumn{2}{|c|}{ Control Group } \\
\hline & $\begin{array}{c}\text { Before } \\
\text { Mean } \pm \\
\text { S.D. }\end{array}$ & $\begin{array}{c}\text { After } \\
\text { Mean } \pm \\
\text { S.D. }\end{array}$ & $\begin{array}{c}\text { Before } \\
\text { Mean } \pm \\
\text { S.D. }\end{array}$ & $\begin{array}{c}\text { After } \\
\text { Mean } \pm \\
\text { S.D. }\end{array}$ \\
\hline FVC & $\begin{array}{c}2495.0 \pm \\
786.74\end{array}$ & $\begin{array}{l}2919.5 \pm \\
684.13^{*}\end{array}$ & $\begin{array}{c}2186.5 \pm \\
847.71\end{array}$ & $\begin{array}{c}2275.5 \pm \\
807.49\end{array}$ \\
\hline $\mathrm{FEV}_{1}$ & $\begin{array}{l}1520.5 \pm \\
653.511 \\
\end{array}$ & $\begin{array}{l}1951.00 \pm \\
617.16^{* *}\end{array}$ & $\begin{array}{c}1396.87 \pm \\
614.18 \\
\end{array}$ & $\begin{array}{r}1483.25 \\
\pm 599.77 \\
\end{array}$ \\
\hline $\begin{array}{l}\mathrm{FEV}_{1} / \mathrm{F} \\
\mathrm{VC} \% \\
\end{array}$ & $\begin{array}{c}63.078 \pm \\
14.02 \\
\end{array}$ & $\begin{array}{c}66.66 \pm \\
12.26\end{array}$ & $\begin{array}{c}62.13 \pm \\
10.88 \\
\end{array}$ & $\begin{array}{c}64.38 \pm \\
10.35 \\
\end{array}$ \\
\hline PEFR & $\begin{array}{c}162.91 \pm \\
109.97\end{array}$ & $\begin{array}{l}224.99 \pm \\
103.32^{*}\end{array}$ & $\begin{array}{c}165.21 \pm \\
89.03\end{array}$ & $\begin{array}{c}194.85 \pm \\
86.80\end{array}$ \\
\hline $\begin{array}{r}\text { Tab } \\
\text { like F }\end{array}$ & Change & $\begin{array}{c}\text { the Pulm } \\
\text { fFEV } 1 / F V \\
\text { groups }\end{array}$ & ry Funct & $\begin{array}{l}\text { Tests } \\
\text { both the }\end{array}$ \\
\hline
\end{tabular}

Data are presented as Mean \pm SD. Paired ' $\mathrm{t}$ ' test. ${ }^{*} \mathrm{p}<0.05$ and ${ }^{* *} \mathrm{p}<0.001$.

Table No. 2 display that after 3 months the change in average FVC value of the control group was not significant, whereas in the study group the changes were found to be significant. Increase in the average FEV1 after 3 months in control group was not found to be significant, whereas in the study group this increase was very significant. After 3 months, the increase in the average $\mathrm{FEV}_{1} / \mathrm{FVC} \%$ of the control group and study group was not found to be significant. The 3 months increase in the average PEFR of the control group was not significant, whereas in the study group it was increased significantly.

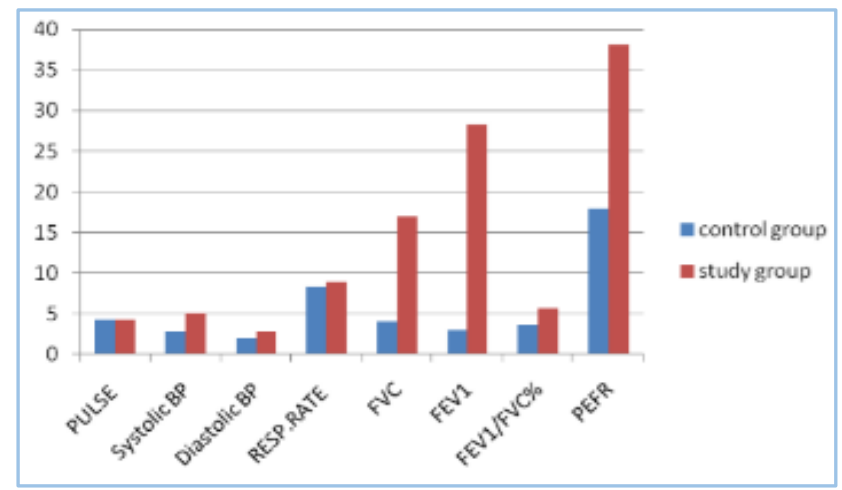

Fig. 1: Percent Change in all the Parameters in both the groups

Before starting the treatment, there is no significant change found in all the parametrs in control and study group (Unpaired ' $\mathrm{t}$ ' test). After three months of treatment, the percent change in all the paramerts were presented and it 
clearly indicate that the change is more in study group and significant for pulse, systolic BP, FEV1 and PEER in study group than control group (Unpaired ' $\mathrm{t}$ ' test).

\section{DISCUSSION}

Yoga is an ancient discipline designed to bring balance and health to the physical, mental, emotional and spiritual dimension of the individual and it is used as an alternative therapy in many chronic illnesses. In present study, the bronchial asthma patients had undergone intervention with yoga therapy, i.e. Pranayam showed a significant improvement in the vital parameters for the patients contacted bronchial asthma. The decrease found in pulse rate in the study group might be due to specific rehabilitative effects of yoga practice on related vital organs improving their microcirculation and thus improving the function. ${ }^{3}$ Crisan HG et al. (1988). ${ }^{5}$ showed a significant reduction in the level of anxiety after the practice of Pranayam, as evidenced by increased skin resistance and a reduction in pulse rate, urinary catecholamine concentration, urinary cholinesterase activity and anxiety scores.

The present study showed a significant fall in the blood pressure of the participant who had undergone pranayam. These findings were correlated with the findings of other studies. ${ }^{6,7,8,9}$ The fall in blood pressure in yoga-trained subject may be due to a decreased sympathetic force caused by pranayam leading to decreased peripheral resistance in the blood vessels.

The improvement in respiratory rate was found among the participants of the study group. This result was similar to other studies.10,11,12 where improvement was found after yogic techniques. While doing Pranayam, the skeletal muscles were relaxed and thus a closed continued voluntary control created over respiratory muscles and it may reduce the rate of respiration to a great deal.10 It has been claimed that yoga practice brings about a significant reduction in basal oxygen demand. 3,9,13

Bronchial asthma is a multifactor disease; clinically, it produces symptoms and signs like dyspnoea (expiratory difficulty), cough and wheezing. Presently, it is difficult to control all the triggers in a single patient. Yoga seems to have a stabilizing effect on bronchial reactivity, thus making the vagal efferent less excitable. Thus, Yoga practice may modify anxiety by the effect on breathing through muscle relaxation and modifying the mental state to induce feelings of wellbeing. ${ }^{14}$ The changes noted in the pulmonary function tests like FVC, FEV1, ratio of FEV1/FVC and PEFR was found to be significant in participants of the study group. The results of this study are also concurrent with the results of several studies. ${ }^{15,16,17}$ It is supposed that the mechanism of improvement in respiratory indicators may be due to the characteristics of pranayam yoga in collaboration of breathing techniques, exhale and inhale.

\section{CONCLUSION}

The present study uncovers the noteworthy effect of pranayamic breathing techniques such as Anuloma-Viloma Pranayam, Bhastrika Pranayam, Kapalbhati Pranayam, Ujjayi Pranayam and Bhramri Pranayam in bronchial asthma patients.

Yoga is useful to alleviate stress and reduce attacks of asthma and it might help in reducing number of hospitalization and expenses on drug.

\section{Limitations of Study}

The sample size and duration of pranayam yoga practice were appropriate but larger community study with longer period of follow up should be carried out to establish yoga as an adjuvant therapy for patients of bronchial asthma.

\section{REFERENCES}

1. Swami Shankardevananda. Yogic management of asthma and diabetes. Published by bihar school of yoga 2002;21:39-41.

2. World Health Organization: Bronchial Asthma Fact sheet. Revised Jan 2000; No 206.

3. Udupa KN, Singh RH, Settiwar RM. Physiological and biochemical studies on the effect of yoga and certain other exercises. Indian Journal of Medical Research 1975;63(4):620-624.

4. Nayak NN, Shankar K. Yoga: a therapeutic approach. Phys Med Rehabil Clin N Am 2004;15(4):783-798.

5. Crisan HG, Nagarathna R, Nagendra HR, et al. Yoga in anxiety neurosis-a scientific study. In proceedings of the international symposium of the royal college of physicians and surgeons of glasgow-update medicine and surgery 1988;192-196.

6. Patel C, North WR. Randomized control trial of yoga and biofeed back in management of hypertension. Lancet 1975;2(7925):93-5.

7. Datey KK, Desmukh SN, Dalvi CP, et al. Yogic exercise in the management of hypertension. Angiology 1969;20(6):325-333.

8. Makwana K, Khirwadkar N, Gupta HC. Effect of shortterm yoga practice on ventilatory function tests. Indian J Physiol Pharmacol 1988;32(3):202-208.

9. Mc Fadden ER Jr Harrison's principles of Internal medicine. In: Fauci SA, Braunwald E, Kasper DL, Hauser SL, longo DL, Jameson, editors. USA: Mc Graw Hill, 2005;p 1511.

10. Nagarathna R, Nagendra HR. Yoga for bronchial asthma: a controlled study. Br Med J 1985;291(6502):1077-9.

11. Goyeche JR, Ago Y, Ikemi Y. Asthma: the yoga perspective part I the somatopsychic imbalance in asthma: towards a holistic therapy. J Asthma Res 1980;17(3):111-21.

12. Nayar HS, Mathur RM, Kumar RS. Effect of yogic exercises on human physical efficiency. Indian Journal of Medical Research 1975;63:1369-1376.

13. Ananda BK, Chinna GS. Investigations on yogis claiming to stop their heart beats. Indian Journal of Medical Research 1961;49(1):82-94.

14. Kozasa EH, Santos RF, Rueda AD, et al. Evaluation of siddha samadhi yoga for anxiety and depression symptoms: a preliminary study. Psychol Rep 2008;103(1):271-274.

15. Singh V, Wisniew SK, Britton T, et al. Effect of yoga breathing exercises (Pranayam) on airway reactivity in subjects with asthma. Lancet 1990;335(8702):13811383.

16. Sodhi C, Singh S, Dandona PK. A study of the effect of yoga training on pulmonary functional in patients with bronchial asthma. Indian Journal Physiology Pharmacology 2008;53(2):169-174.

17. Erskine J, Shoneel M. Relaxation technique in bronchial asthma. Psychosomatic Res 1971;25:139-142. 